\title{
AN OVERVIEW OF THE THEORETICAL FOUNDATIONS OF PUBLIC SPACES WITH AN EMPHASIS ON URBAN SQUARES
}

\author{
Niki Amiri \\ Master of Architecture, Islamic Azad University, Babol, Iran \\ Nik.amiri@yahoo.com
}

\begin{abstract}
With glance at the various fields in the past, present and urban public space as well as comparative in the fabric of the constituent elements such as sidewalks, paving, communication, activities and many other areas of physical criteria and space can achieved the positive or negative results such the feeling of Ghana, discipline, balance, flexibility, vitality, consistent sense of being trapped, landmarks, monuments, identity, spirit, activity and many other factors. Most urban squares in cities, especially in the new part, reflect the fact that these spaces are designed in a logical continuation of the past. In other words, not only the principles of urbanism and architecture and urban design ignored, but also the principles and criteria were not received logical spaces not only for the present but for the future would be inappropriate and alien. Therefore, the importance of the theoretical foundations of urban spaces among designers and architects, especially in the field of design over and over gets the feeling that this important issue has been discussed in this study. Methodology and data collection was libraries (observation and interview), respectively.
\end{abstract}

Keywords: urbanism, architecture, urban space, field.

\section{INTRODUCTION}

Public space is generally interpreted in two ways. A public space with an immaterial nature that goes back to the ideas and values within a community and the general atmosphere of the nature of the material that represents the physical realms urban community. The recent concept had physical approach that has marked the city's streets and squares.

Square is Play field for the life of a city, shows movement, vitality, effort of its citizens to live. Square with the layout and composition identity the city and the identity of its inhabitants. Power, creativity, art and perfection of the people is in it. Indicate the love of life and love to the collective aspirations. Order and cleanliness and peace of mind of people are in it. If you want to know the city, visit the field of the public, the city is reflected in the small mirror perfected its squares. Reviewing the history of the city is enough; In East and West in the Old and New, long-term field as an urban element, in different sizes and shapes, there have been settled communities scene into history. But this article is not to nuance and complexity of the historical and social evolution of the field and its surrounds but evaluative study, from the perspective of professional and urban design to this important element of urban, to see at this time, how are we and our cities, what's happening to the squares that we had.

\section{PROBLEM STATEMENT}

In this study of cities and settlements throughout history, three-way or three historical periods can be identified. In the first period, cities and areas, sales were essentially market squares; in the second period, cities were centers of industrial production in the third period, cities were formed on the basis of the establishment of logistics centers and consumer services. The main pillars of development and 
development of cities are the need for people to gather. These needs include security and defense purposes, trade and exchange of goods and services or access information, participate in or organize activities that require common effort and so emanate.Main factor in urban public spaces are, activities that are needed by people to communicate with each other. This means being at one time and in one place. Gathering of people in a space and time will facilitate an important social dimension, which later came to be known as the nature of the city in a cultural sense. Without mass public places in people's lives, mission is in trouble. For the urban area of nutrition and strengthening of communication and public relations diversity that is the essence of the city remains (Carmona,2009).

Public spaces such as streets, squares and urban nodes valuable role for urban planning and design .This is due to the influence of the social and cultural aspects of urban spaces and thus produce social capital. In the meantime, city squares due to their special nature and their performance in spatial and physical structure of the city and as well as the mental reproduction of meaningful role urban public space areas are the most effective area of a city in the minds of citizens (Pakzad,2005).

Considering the importance of the present research scholars on the subject of the theoretical basis of public spaces with an emphasis on urban squares and researchers and designers to focus on design and review was conducted in urban areas, especially in city squares. -urban space

One of the city's urban spaces building space that comes with the history of a nation is created in different periods, forms and changes. Urban space, outer space and public life of the city in which it occurs and the two main components of streets and a square are formed. A basic condition for an urban environment, social interactions taking place in it. From the perspective of urban space doctor Pakzad five main types are: input nodes, paths, edges, water and stairs. The nodes, which have influence on the minds of citizens that is the focus, may be on the field, gathering place or at the gate of segregation. Nodes, including the local, municipal, ceremonial and bolts are a total of nodes, stability, aggregation-taking and consolidation is expected (Ebrahimi, 2009).

During different historical periods, often behaviors of people as well as design and layout features private and public spaces were similar and were influenced by each other. Studies show that the first measure that human use of urban space is square. Square arises from the accumulation of houses around an open space. The most appropriate function for the carrier, business, cultural and residential. Some researchers believe that the only role of today's cities is not right gate (Pakzad, 2006).

\section{IMPORTANCE OF URBAN PUBLIC SPACES}

In contemporary cities, urban public spaces of the city are one of the fundamental components which had the social and physical concepts. Urban public spaces in the most general sense as a physical reflection of the current cities are considered public domain. These spaces due to one or more physical characteristics or space for face-to-face relations, public experience of the space, the human relationship with the urban fabric and holding the collective efforts of public and citizens have been designed and crafted.

Public spaces feature can be briefly described as follows:

- The ownership of the spaces is for all citizens and for public use and is universal;

- In these spaces, in addition to the distinction space and body, conduct significantly changed.

As a result, arbitrary and freely place to behaviors that lead to solidarity and interests of citizens; these spaces are free from domination by car and by creating peace of mind, security and behavior of humancentered creates environment and more engaging for spending leisure time (Massoud,2007). 
One of the simplest methods of classification of urban public spaces is, dividing it into two main spaces and spaces pause motion. In this way, a movement corridor spaces and the spaces are called pause.

Importance of the physical and social fabric squares in cities highlights, the poverty shape our space in urban public spaces. Today, city squares and the nature of their primary function are lost and space has become mere traffic. The field is too small or large, crowded and polluted air and visual, adverse landscape and buildings around the square inappropriate factors that have caused the decline of public spaces.

A city has spaces for public life and social relationships on their citizens. What is the appeal of the town and its memories, its squares . A field when it can be called urban plaza that also have a social function, a place for gatherings and social activities and human relationships and society.

\section{CONCEPT OF ENVIRONMENTAL QUALITY}

In Dehkhoda dictionary definition meaning "state or a condition that results in something", equivalent quality in Webster's Dictionary means "how good or bad thing are" and the Oxford dictionary "measurement standards in something compared with other similar things ". On the other hand the common definitions of the word, quality means "the good and worth of something" (Oxford).

Quality is a thing or a phenomenon that particularly impact on one's emotional and intellectual. Quality differentiates the phenomena of time and can be obtained form (formal or formal qualities), performance (performance) or sense (quality concept). So the quality of urban spaces can be divided into two categories:

- Quality-forming space structures and forms (forms and shapes).

- Quality of compatibility between the components space (form, function and meaning).

Whatever humans belonging to a space more the space qualified higher quality. This requires that space and put more people audience is interacting with him, meet his needs and behavior patterns is suitable container. In other words have more meaning for viewers and users to understand, done easier and faster. Urban spaces as well as other phenomena have meaning components, performance and form requirements.

No matter how these components together is beyond space quality gets better and more harmonious. There is a variety that define the quality of a man's hand, and also hierarchical perception that the quality is perceived by both its objective and subjective aspects, on the other hand, has caused a variety of quality arise. In the simplest classification quality can be divided into two categories: quality real and the quality of mind. Accordingly, the qualities that belong to the realm of subjective quality in mind are that are resident within the realm of objective and mutually related quality-called real qualities, which are qualities belonging to the object and the foreign entity subject to the mind and the outside world and deal with the real (Golkar,2001).

\section{SOME THEORIES OF ENVIRONMENTAL QUALITY}

Among the numerous works that have studied the factors and indicators of environmental quality, the report only mentions a number of important theories in this field are until after they review a framework for understanding environmental quality can be achieved.

In 1961 Jane Jacobs in The Life and Death of America's great cities, high-quality environment suggests the following criteria: 
- Pay attention to create appropriate activities in the environment before considering its visual order;

- Use mixed land uses in terms of both architecture and buildings;

- Emphasize the street and the influences viability (availability) is relative to surrounding tissue;

- Incorporation of social and flexibility of spaces

Kevin Lynch in 1981 in Good City Form examine mainly large-scale this issue and believes vitality along with five other factor meaning, relevance, access, control and discretion, efficiency and equity, functional axes good shape make up the city. Lynch won the status of a public space should be such that:

- Receptive many people. Also nearby retail centers that are attractive and pedestrian-producing activities.

- Its size should be such that mass entertainment and events have the capacity, but not so large that it will destroy closeness;

- Create a vibrant space is possible, surrounded by retail shops, restaurants and bars are surrounded;

- Design space should increase its capacity to attract and compliance activities. In this regard, urban furniture, flexible use, convenience, compatibility, high quality and simplicity of the important factors are high (Lynch, 2008).

Ian Bentley in 1985 and in environments respondents, the collection has studied urban design qualities. Bentley and colleagues states 7 criteria (components) that should create an environment of respondents (qualified) are adhered to the following:

1. Permeability;

2. Diversity;

3. Readability;

4. Flexibility;

5. Visual proportions;

6. Sensory richness;

7. Color belong (Bentley,2003).

David Kanter and John Panther pioneer of environmental quality studies in 1990 introduced a model called "model site", the urban environment consists of three intertwined bodies; the activities (performance) and (perception).

All that these three components each task they meet one of three quality physical activity and environment are responsible sense.

It is also one of the most important theories about the quality of the physical environment, was published in 2003 by Matthew Carmona. In this work with public urban spaces as places, Carmona effective quality physical environment is divided into the following components: 
- Structural factors: access to space;

- Conceptual or semantic components: public space, security and urban landscape;

- Social components: inclusive of the space;

- Visual components: hardness and softness space;

- Functional components: mixing and compaction performance;

- The time component of time management using space.

The theory of similarities and differences in perceptions of the quality of the environment and key metrics that theorists have offered to provide a qualified environment. A review of these theories, we can now provide a framework for understanding the quality of urban space.

As noted urban space consists of three intertwined structure, function and perception. Accordingly, the recommendations in this report are based on quality components to meet design environment to the fields of functional, structural and conceptual (semantic) space measures. It can be five criteria for assessing the quality of the environment is as follows:

- The construction and proper form;

- Existence of functional diversity;

- Despite the vitality and charm in space;

- Identity and unique features;

- There are visual proportions and sensory richness.

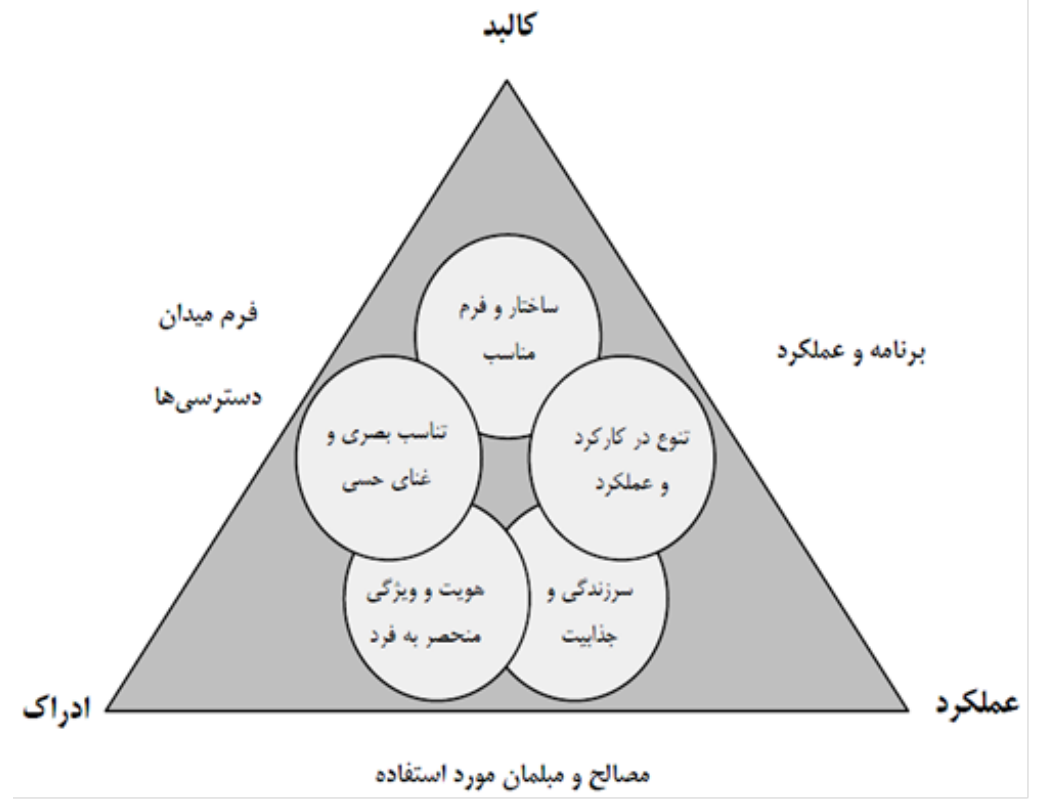

Figure (1): proposed model for measuring the quality of the environment 
(Center for the Study of Tehran Urban Planning, 1392

Improve the quality of urban public space planning process is based on guidelines and criteria with expectations, requirements and users of space affects behavior, the functions, the operation, activities and social implications.

Therefore, this model should be different elements and indicators that have to be carefully considered in relation to the quality of the environment and also operate their experiences. Customer recommendations planning can communicate with vitality, the diversity, the richness of ideas and visual quality to cause a public space. Based on the criteria seem to be four main components that form the square, surrounding access, schedule and performance as well as the materials, equipment and furniture used over other elements and components of a field can be used for quality and improving the quality factors contribute Square (center for the study of Tehran urban planning,2013).

\section{SQUARE}

Persian culture means the earth in certain fields, arenas and facilities of the few streets that connect them. Square is a dramatic arena for the life of a city and moving the attempt to give life and vitality of its citizens informed. The design and composition to the city's identity and secure the originality of its inhabitants. This field indicates the strength, creativity, art and friendliness of the people perfection the love of life and love story of the collective aspirations. A brief review Square the historical evolution of ancient cities so far, suggests that, with time, Square city had an influential role in the collection of organs, and great effects on the formation and spatial organization of the city to different historical periods. Square as urban space with human presence and significant pause, to a certain intention in relation to population movement has emerged. In addition to its effects on the creation of a space of communication, contacts and activities reveal a man (Abraham,2009). Square has always had a special meaning in the minds of citizens. Despite changes in form and function to the reasons mentioned above, this image will not be changed. Square subject to spatial and temporal role and has taken various functions. Sometimes it was a place for the supply of goods and sometimes for the government and the Court or religious. In modern times many of its functions were transferred to buildings. Due to the current situation, different functions of society in the past can not be expected (Naghi Zadeh,2006).

\section{RATIONALES FOR SQUARE}

Anywhere in population density, village, City or Metropolis, human group life sometimes requires certain public functions that unavoidable gathering of large number of residents. There is a central gathering point for the community and always the easiest and most logical business solution has been to meet these needs. And especially when human movement and transportation was implemented in scale, performance is good. Residents of a city, urban access to a range of internal and external production and has opened its requirements have been raised. If small town right - weekly or monthly market was formed in it, if a large and heavily populated, right - its market standing was designed. Although the main performance is, community and commerce that sometimes functions were no longer needed to focus on the importance and ability to meet this increase. Especially if you also need the functions inherent to a more open space than a simple crossing or adjacent to urban access roads were normal. Integration in the field is - more and more necessary to be serious market. At the beginning of temples and other places of worship, the point is immanent to rallies and meetings were priests and pilgrims. The continuation of general performance, margin and adjacent space these places become fertile ground for social and other public services such as artisans, vendors, beggars and others have been invited to attend and activities. Organize the activities necessary to fulfill their tasks other hand, such as policing, monitoring the legal trade and prevent personal conflicts, theft and violence, as well as receiving tax. On the whole reason for disrespecting police forces and government agents (Zucker, 2006). Therefore, there has also been a 
perfect space available. The primary criteria for the design of such a situation are the prerequisites by the actions of religious, economic, political and recreational involves the formation of the right - is the traditional market had been dictated. Composition and design of the historic market in various regions and periods from this angle is, reasonable and necessary and inevitable in response to the functions of cities. Agora, Forum, Market Square, Piazza and The Plaza has different names. In urban communities are given the same performance. Despite different measures changes in the pattern design and culture of each society, all initial units have been designed according to the need and concept (Ebrahimi,2009).

\section{TYPE AND MAIN FUNCTION OF SQUARE}

Since the introduction of Square concept, types and functions Square are one of the important factors but disappeared adjust and mix in place of or in any Square of activity. As naturally suburban business in a field that was built in lacks space Such as Square sales, sheep, horse sales, etc. took place in outdoor. Each group was settled in part of the Square. While in a field important rule, at least in front of the mansion Outdoor government there was no less important activities such as retail, the sale. It rarely happens that used the neighborhood squares to open a permanent basis for buying and selling (Soltanzadeh, 2006). According to a proposed categorization fields on the basis of their performance are divided to the public, the business, the government, the military, neighborhood squares, sports fields and fields communication. Other views are also different categories of action taken. Different categories of fields from other views also took place. Including the classification of Square information that Zucker does. They are divided into five categories that include Square fenced and closed the dominant Square, nuclear Square, fields collectively, Square amorphous (Nazari Razie and Begay,2011).

\section{THE BULK PROPERTIES OF SQUARE CLOSED SQUARE}

It is the surrounding space bodies. But this is not an absolute being trapped, because the passages that lead to this space, in the body requires openness. To maintain the blockade by using elements such as arches, entries body masks. Like Square "Meyer" in Madrid, Spain. Sometimes independent buildings form Square bodies, which are located side by side, (Scheme 2 ).

\section{OPEN FIELD}

There is space around the building. The result is often the art of gardening determined with trees and shrubs planted in certain places and keeping things in order. These fields are more to decorate residential areas. The difference between the fields of urban parks, among other limitations is in the size and shape of clear space by trees (Scheme 1). 


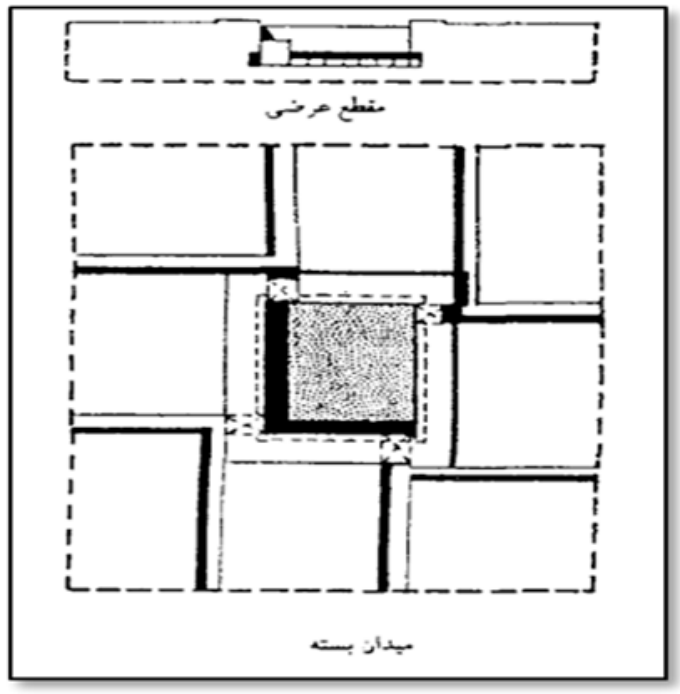

Numbering plan (2): Square closed

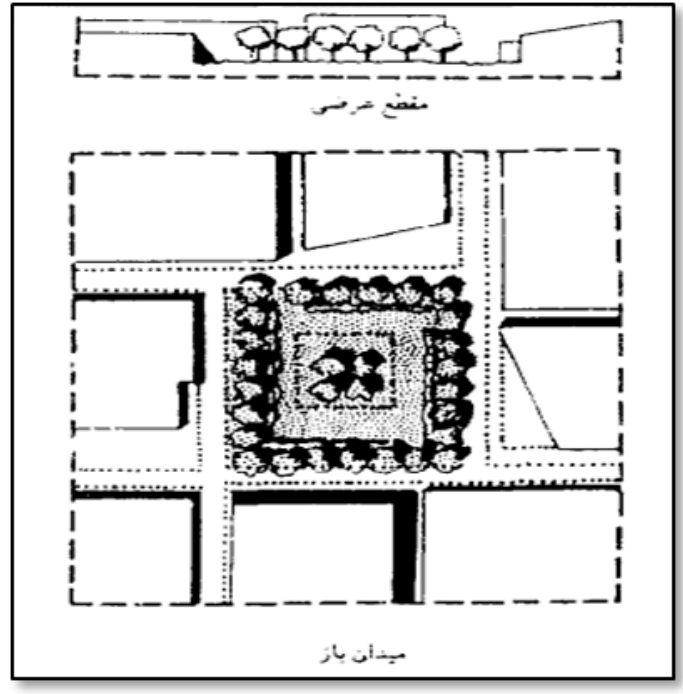

Numbering Plan (1): open

\section{HALF-OPEN}

Space is formed often at the roadside next to the last. The fourth body or wide open space. Or a transparent body, by trees, bushes or columns is enclosed. Many features of English gardens are the same (scheme 4).

\section{SQUARE AND THE DOMINANT BUILDING ON IT}

An area that is mostly used in urban planning. A major public building, dominating the Square, located on the edge of it, as proportion of it can include Square full space and vice versa. In this situation only unique architecture and dominate is its space field. Even overshadowed the other features of its own. Structures are created that increasingly influence, can build a mosque, a government agency, museum and theater (design 3). 

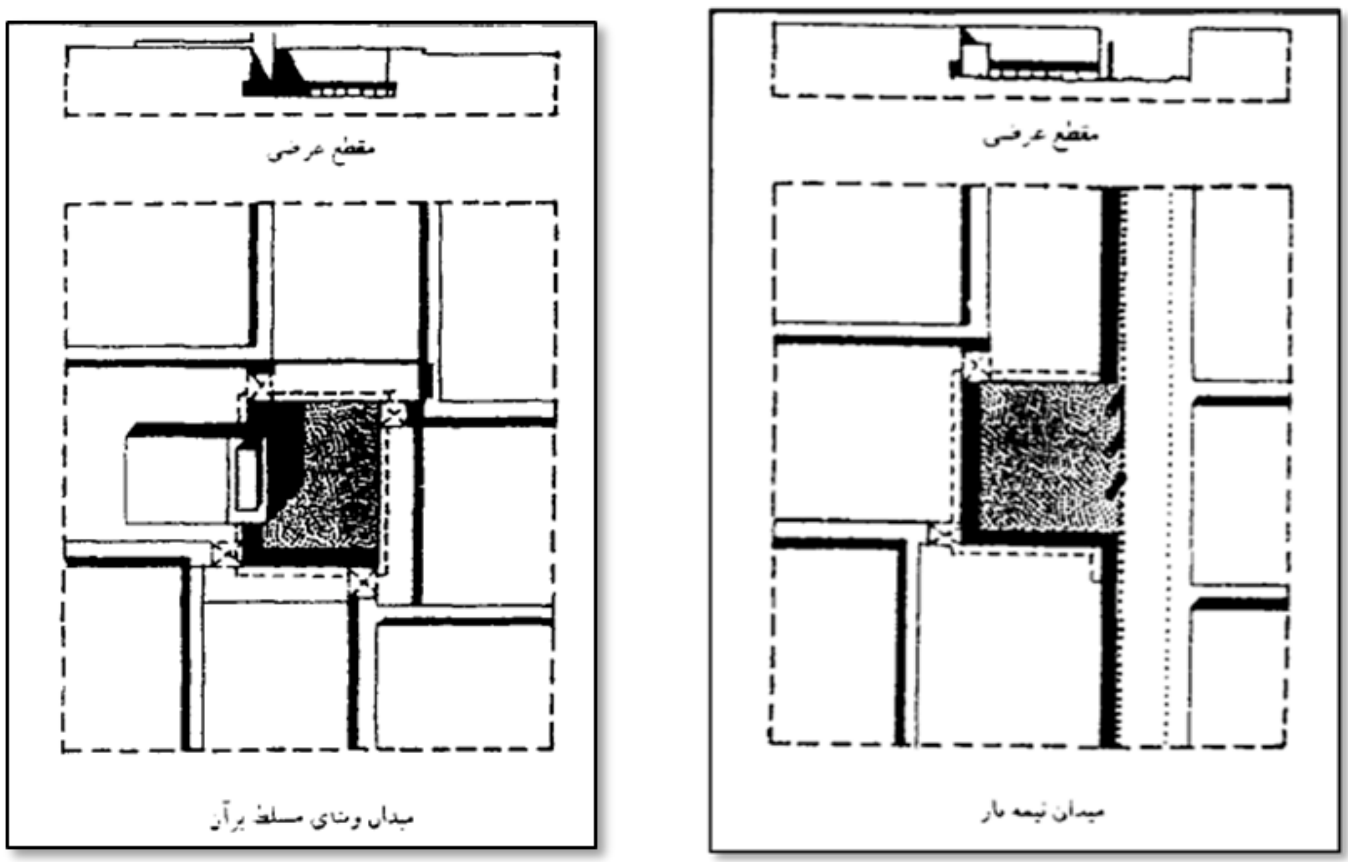

Numbering Plan (3): Fluent in its Square and building Square

Numbering plan (4): Semi-open

\section{DIVIDED SQUARE}

Space is formed a number of other areas that are related. In the past, this type of space is usually when elected and should have an important place of the city, the seat of government built. The most famous squares are, Piazza San Marco in Venice Pyazta (Project No. 5).

\section{STAR-SHAPED OR CENTRAL SQUARE}

Circular space at the end of the nineteenth century was designed generally to the development of cities (more circular shape is inspired by and based on how the car is moving). This space, the axes are focused to a point, connected to the streets and alleys. Emphasizes the lines of the city's physical orientation. The beautiful view to the fountain, statues and memorial columns creates the middle of the field. Etoile Square the triumphal arch victory in Paris and Tehran's Azadi Square are examples of this type of field (plot number 6). 


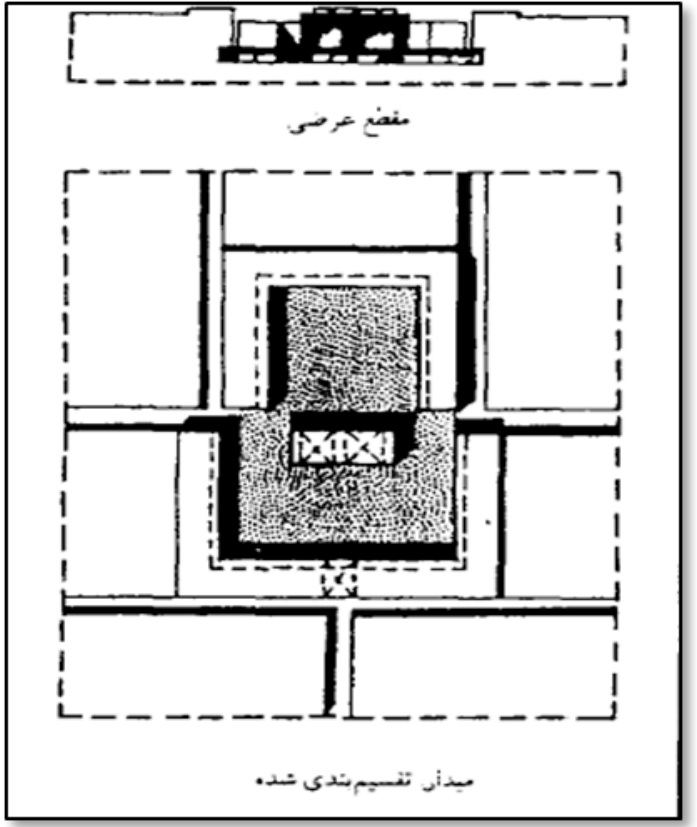

Plan (5): divided Square numbering

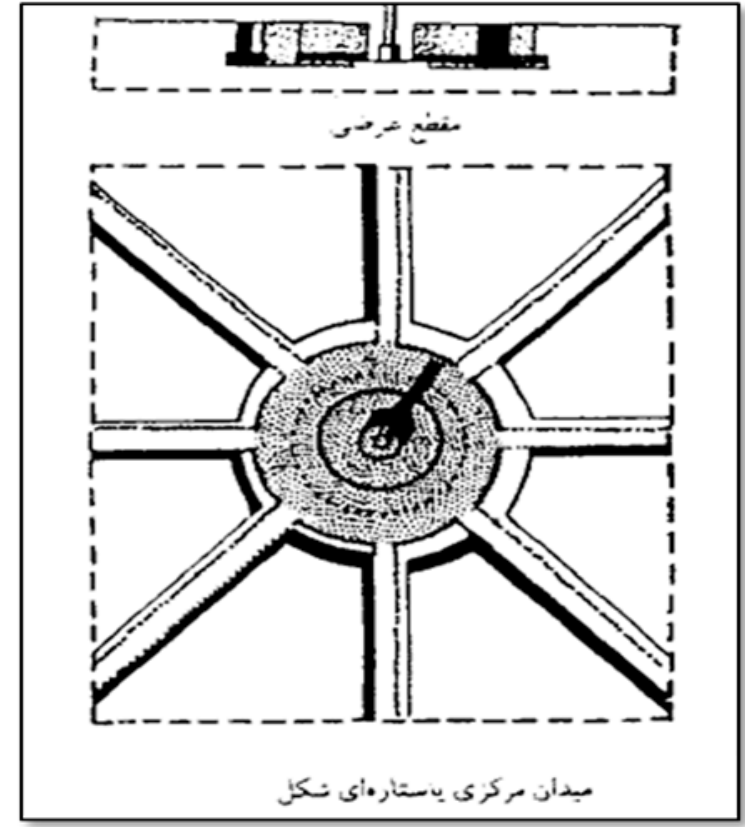

plan (6) star-shaped or central square

\section{LONG AND STRETCHED SQUARE}

Space is shaped by the development of a street. Many past street markets, in this type of field were created. Today in regions and areas where there is understanding, and harmony between mounted and dismounted traffic, such as residential areas, $(30 \mathrm{~km}$ per hour speed limit for motor vehicles and pedestrian right of way), this type of field can be see (scheme 7).

\section{MODERN SQUARE}

But individual buildings close to each other with geometric regularity and occupy a certain space. The combination of these volumes together and empty spaces between them in relation to the ground, and one man creates architectural. This is an example of square modern design (plan No. 8). Berlin Alexanderplatz design competition "Mies van der rohe" Square plan was presented this way (Hdmn and Yazvsky,2006). 

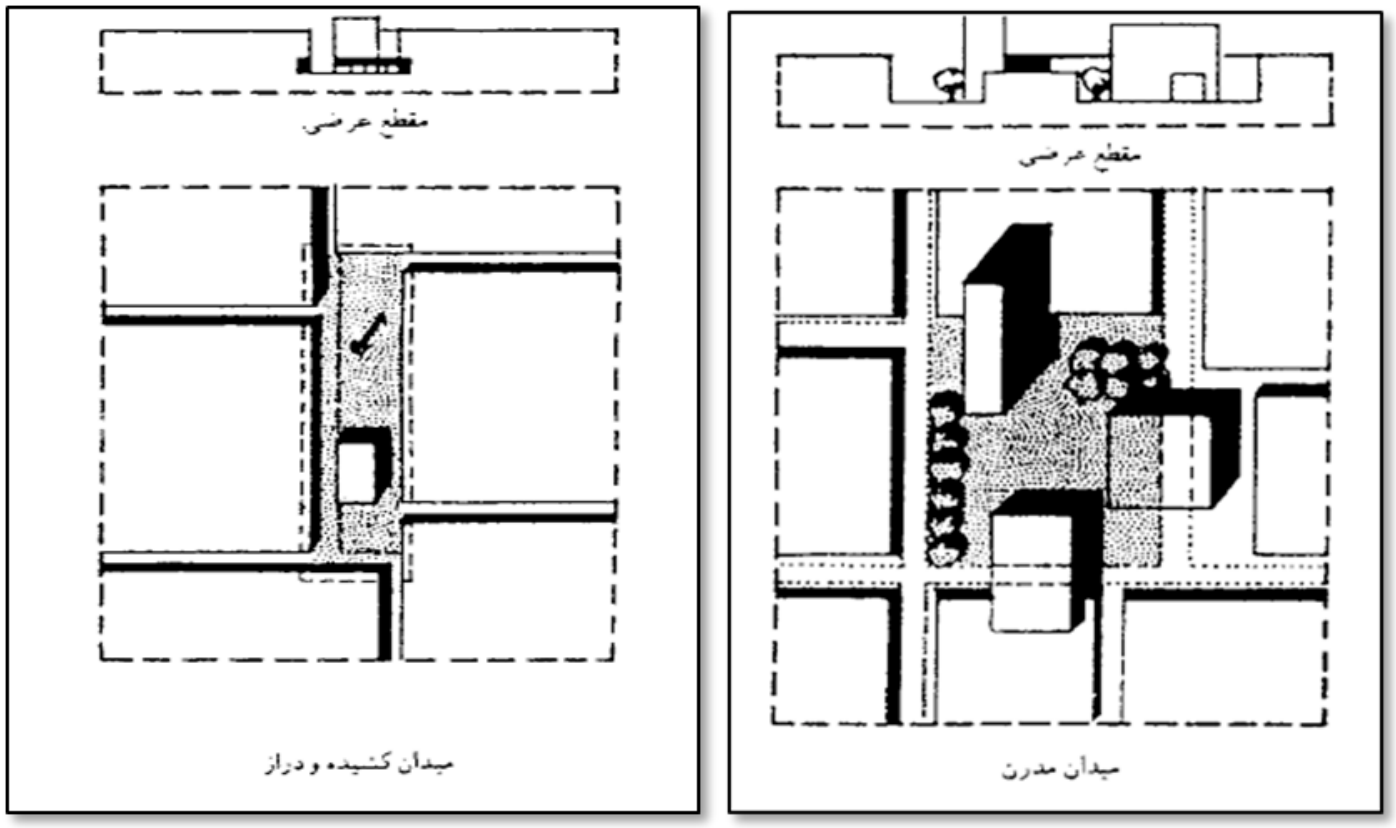

Numbering Plan (7): Square long and stretched

numbering plan (8): Modern Square

\section{EFFECTIVE CRITERIA FOR QUALITY SQUARE SQUARE FORM}

Square forms an important part of the design process and shaping the urban landscape. The perception of space and its quality is very important. In terms of performance could also limits Square space in front of traffic passing vehicles instead of fences and protective bars, determine. Square in shape, it is important to understand visual form. This understanding of the elements Square the floor, the body is determined and openness. Axes track and Square form also specifies and defines the threshold of space. In this way we can increase Square importance of buildings and objects in space. Fenced off and access, describes the function of Square body. So how confined the space differently, the impact is especially effective space. Through building surfaces, characterized Square. You can also plan your body square and surrounding streets extended to adjacent edges. Since the space of each Square mainly takes the form of access, passages and paths as the edges of Square and its surrounding elements are important (I Wong and Singh, 2005).

\section{DETERMINE HOW TO ACCESS}

Field enclosures and position in relation to its streets, has a great effect on the functioning and effectiveness of Square. Based on new design ideas, are designed squares that although the traffic comes in contact with, but should not be bisected by it on or off. Access can also create a login and openness to the field and can enclose Square space and the space around them separate. In this case the Square is crucial for navigation and routing vehicles (Pasyvn, 2005).

\section{CAREFULLY USED MATERIALS AND FURNITURE}

Square surface texture and properties of the surface such as design, color, and composition determined quality characteristics Square the materials. Surface design represents Square different functions and the type of solid surfaces with paving, paving, asphalt, concrete and other solid surfaces with rubble, sand, grass, as well as the borders and dividing lines, tables, corners, stairs, fences, Turret, protective walls, gutters and so on. So the field can Square spaces, elements and connect it to the body. Would require 
them or separate members. So it should be a map and a diagram analysis includes all materials and equipment used, such as rocks, plants, wood, iron, wood, water and asphalt to reshape and features on the space provided. The most important factors shaping Square environment, objects and open spaces are certain elements that set. Columns, fountains, sculptures, pavilions, etc. are among these elements. On the other hand planting trees, flags, spars, hull lights and ventilation are also part of these elements. On the other hand dimensions, proportions and position of the elements and most importantly, form and function are important criteria that should be considered in the design (Van Camp et al., 2003).

\section{PROGRAM AND SQUARE PERFORMANCE}

Square most important stimulus programs and attractions to create a public space and are also the nature and identity. The main factor Square success is, vitality and flexible operation at any time of day or night. Square program can also stream coordinate the activities and support them. Initial ideas for programming could include the following measures:

- Holding the ceremonies and rituals related to the seasons;

- Provide a game space and meeting people;

- Design visually appealing messages;

- Artistic activities, displays, musicians and so on.

- Create space for public debate;

- Create teahouse, restaurant and so on;

- Lighting and decoration.

Table (1): components and indicators measuring the quality of urban public squares

\begin{tabular}{|c|c|c|c|c|}
\hline Concept & Field & Criterion & Component & Index \\
\hline \multirow{8}{*}{ 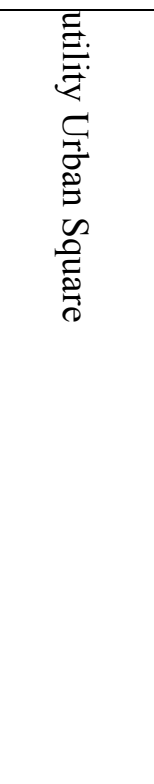 } & \multirow{4}{*}{ Body } & \multirow{4}{*}{$\begin{array}{l}\text { The structure } \\
\text { and proper } \\
\text { form }\end{array}$} & Square Form & Body and distinctive edges \\
\hline & & & Access & Urban street network connection \\
\hline & & & $\begin{array}{l}\text { Materials and } \\
\text { furniture }\end{array}$ & $\begin{array}{l}\text { Strengthening the structure and form of } \\
\text { furniture, flooring, etc. }\end{array}$ \\
\hline & & & $\begin{array}{l}\text { Planning and } \\
\text { Performance }\end{array}$ & User continuity in the sub-body and glazed \\
\hline & \multirow{4}{*}{ Function } & \multirow{4}{*}{$\begin{array}{l}\text { Visual and } \\
\text { sensory } \\
\text { richness of } \\
\text { match }\end{array}$} & Square Form & $\begin{array}{l}\text { The ability to sit back, relax and chat in the } \\
\text { square }\end{array}$ \\
\hline & & & Access & Equal access mounted and dismounted \\
\hline & & & $\begin{array}{l}\text { Materials and } \\
\text { furniture }\end{array}$ & $\begin{array}{l}\text { Diversity and harmony in the use of materials, } \\
\text { equipment and furniture }\end{array}$ \\
\hline & & & $\begin{array}{l}\text { Planning and } \\
\text { Performance }\end{array}$ & $\begin{array}{l}\text { Variation in the use of space (in terms of time, } \\
\text { personnel, etc.) } \\
\text { Strengthen neighborhoods and regional nature } \\
\text { center }\end{array}$ \\
\hline
\end{tabular}




\begin{tabular}{|c|c|c|c|}
\hline \multirow{8}{*}{ Perceptual } & \multirow{4}{*}{$\begin{array}{l}\text { Despite the } \\
\text { vitality and } \\
\text { charm in } \\
\text { space }\end{array}$} & Square Form & $\begin{array}{l}\text { Use the edge of space } \\
\text { Its different parts of our environment. }\end{array}$ \\
\hline & & Access & Its convenient walking route to the Square \\
\hline & & $\begin{array}{l}\text { Materials and } \\
\text { furniture }\end{array}$ & $\begin{array}{l}\text { Diversity and harmony in the use of materials, } \\
\text { equipment and furniture }\end{array}$ \\
\hline & & $\begin{array}{l}\text { Planning and } \\
\text { Performance }\end{array}$ & $\begin{array}{l}\text { Ability to set up a temporary markets } \\
\text { The use of natural and environmental } \\
\text { attraction } \\
\text { The user having the neighborhood }\end{array}$ \\
\hline & \multirow{4}{*}{$\begin{array}{l}\text { Identity and } \\
\text { unique } \\
\text { features }\end{array}$} & Square Form & Increase readability limits of space \\
\hline & & Access & $\begin{array}{l}\text { The definition of Square edges of the street } \\
\text { network }\end{array}$ \\
\hline & & $\begin{array}{l}\text { Materials and } \\
\text { furniture }\end{array}$ & $\begin{array}{l}\text { Harmony and contrasts in materials, building } \\
\text { materials, furniture }\end{array}$ \\
\hline & & $\begin{array}{l}\text { Planning and } \\
\text { Performance }\end{array}$ & $\begin{array}{l}\text { Revealing the historical continuity of space } \\
\text { Having the complexity and specific } \\
\text { performance }\end{array}$ \\
\hline
\end{tabular}

\section{CONCLUSION}

Any city, however small, can boast of having the beautiful and noble field, provided that all the important buildings are gathered there, like an exhibition that case, the value of other items. How to design green spaces, fountains, statues and sculptures used in urban squares in the environmental balance, mental relaxation and beautification of urban citizens plays an important role.

The most important element is making city squares space. Always is formed by history of a nation that occurs in different periods. This element of the different activities of cultural, economic, social and ... always hold in it, always pulsed at the heart of the city history and the figure history of the cities. So do not think that it is an element of the old Urban and cities does not need today. Do the new phenomena such as satellite communications, the Internet and in other cases still unable to take the Square. But also town squares is crystallization of the collective life of the citizens of a city.

Given the importance of this issue, according to the principles and the theoretical basis of urban studies and urban design in particular fields can solve many problems of these spaces and provide growth and development of cities.

\section{REFERENCES}

1. Abraham, Muhammad Hassan (2009), the spaces not defined in Iran, Journal identity of the city, Issue 4.

2. Bentley, Yan and colleagues (2003), responsive environments, Mustafa B. oven, University of Science and Technology, Tehran.

3. Reza-Zadeh, R. and Mir Haydar, S. (2012), designed Mashhad railway field, relying on the principles of environmental perceptions, Journal of the Association of Iranian Architectural, Issue 4.

4. Soltanzadeh, H. (2006), the urban space in the historical context of Iran Cultural Research Bureau in Tehran.

5.Qarib , F. (1997), the town of Fine Arts Magazine, Issue 2.

6. Golkar, K. (2001), urban design and urban planning policy fine design, general journal, Issue 46. 
7. Golkar, K. (2000), parameters of quality urban design, Journal of account, (3).

8. Golkar, K. (2000), parameters of quality of urban environment, No. 32, publication Shahid Beheshti University, Tehran.

9. Carmona, Matthew (2009), public places, urban spaces, translator Fariba recitations and colleagues, University of Art, Tehran.

10. Planning \& Research Center in Tehran (2013), the factors affecting the quality of fields, with a view to promoting urban design, infrastructure planning and design department, and comprehensive studies, management studies and architectural planning, urban affairs and crisis.

11. Hdmn, Richard and Yazvsky, Andreo and Reza Zadeh, R. (2006), the principles of urban design, translation Razia Mostafa Zadeh and Abbaszadegan, University of Science and Technology, Tehran.

12.Nazari , Slda and Rzabygy, R. (2011), field: a space for the development of social interaction and design solutions, the Third National Conference on Urban Development.

13. Naghizadeh, M. (2006), Reflections on the process of reform in Iran, Journal of Fine Arts, Issue 25.

14. Lynch, Kevin (2000), well in theory, translated by Seyyed Hossein Bahrain, Tehran University Press.

15. Masoudi, K. (2007), urban public spaces: the place of social interaction, municipalities Magazine, Issue 26.

16.Nichol, Janet., Wong, Sing Man (2005), Modeling Urban Environmental Quality in a Tropical City, Landscape and Urban Planning 73, 49-58.

17.Pacione, Michael (2003), Urban Environmental Quality and Human Wellbeing a Social Geographical Perspective, Landscape and Urban Planning 65, 18-30.

18.Van Kamp, I., Leidelmeijer, K., Marsman, G., Hollander, A.D. (2003), Urban Environmental Quality and Human Well-being towards a Conceptual Framework and Demarcation of Concepts; a Literature Study, Landscape and Urban Planning 65, 5-18.

19zuker, paul (2006), Town and square from agora to the village, the M.I.T press, Cambridge, Massachusetts, London, England. 